\title{
Dominance of the Wild-type Alleles of Methionine Regulatory Genes in Salmonella typhimurium
}

\author{
By K. F. CHATER* \\ Genetics Department, The University, Birmingham I5
}

(Accepted for publication 22 June 1970)

\begin{abstract}
SUMMARY
$\mathrm{F}^{\prime}$ elements carrying wild-type alleles of the methionine regulatory genes met $J$ and $K$ have been transferred from Escherichia coli to metJ and $K$ mutants of Salmonella typhimurium, and the resulting heterogenotes tested for resistance to methionine analogues and for repressibility of cystathionase (one of the methionine biosynthetic enzymes). The wild-type alleles of both genes were dominant in both tests. Increased met $K$ gene dosage was found to have no effect on the rate of uptake of $\left[{ }^{14} \mathrm{C}\right]$ methionine by cell suspensions. Possible roles for the met $J$ and $K$ gene products in the regulation of methionine synthesis are considered.
\end{abstract}

\section{INTRODUCTION}

The six structural genes controlling methionine biosynthesis in Salmonella typhimurium are not contiguous (Fig. I; Smith, I96I ; Sanderson \& Demerec, I965; Childs \& Smith, 1969), and the repression of their expression by exogenous methionine appears not to be co-ordinate (Lawrence, Smith \& Rowbury, 1968). Two kinds of mutants in which expression of these genes was constitutive were found among mutants resistant to methionine analogues (Lawrence et al. 1968). met $J$ mutants were resistant to DL-ethionine, but not to $\alpha$-methyl-DL-methionine or DL-norleucine, while metK mutants were resistant to all three analogues. Some met $K$ mutants were also isolated in which regulation was normal, and, unlike constitutive met $K$ mutants, these did not show a reduced growth rate in minimal medium compared with the wild-type. met $J$ mutations were about $95 \%$ cotransduced with $m e t B$, and met $K$ mutations about I \% with $\operatorname{ser} A$ (Fig. I).

In the present work $\mathrm{F}^{\prime}$ episomes carrying, respectively, the met $B$ and $\operatorname{ser} A$ regions of the Escherichia coli genome (K. Brooks Low, personal communication) have been transferred into Salmonella typhimurium strains, and the dominance of various met $J$ and $K$ alleles tested in the resulting hybrid heterogenotes. The possibility that met $K$ may specify a component required for methionine uptake has also been tested, by examining the effect of increasing the met $K$ gene dosage on the rate of uptake of radioactive methionine.

\footnotetext{
* Present address: John Innes Institute, Colney Lane, Norwich, NOR 7oF.
} 


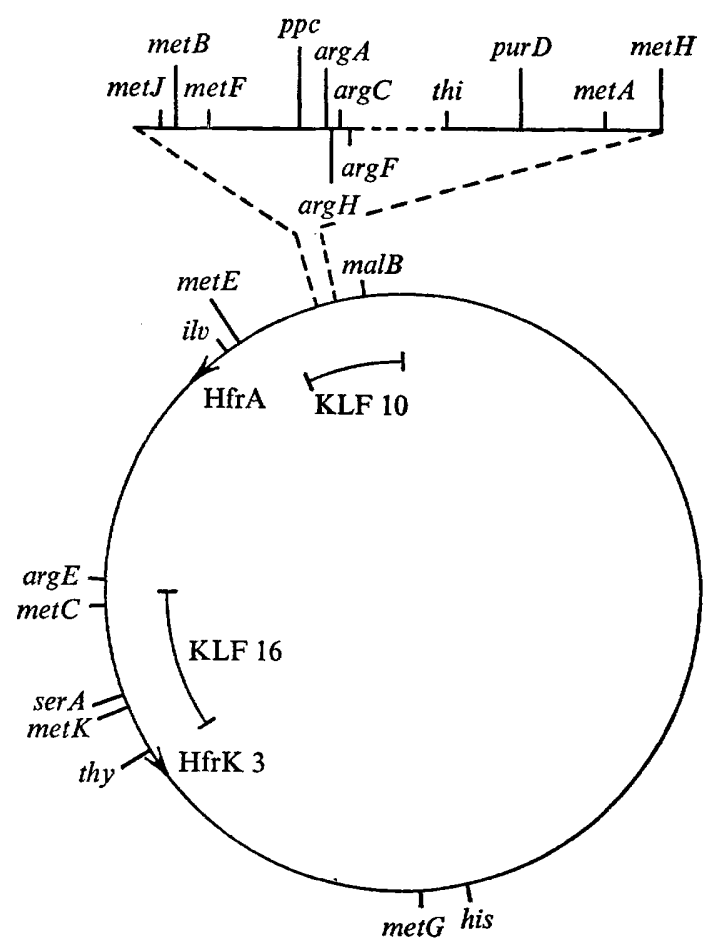

Fig. I. Linkage map of Salmonella typhimurium. The map and nomenclature are based on those of Sanderson (1967). Bracketed markers are cotransduced. Arrows represent the sites of insertion of sex factors in high frequency donors. KLF 10 and KLF 16 represent $F^{\prime}$ episomes derived from Escherichia coli by $\mathrm{K}$. Brooks Low, and carrying regions of the $E$. coli genome homologous with the regions of the $S$. typhimurium genome covered by the arcs.

\section{METHODS}

Media. Nutrient agar (NA) and nutrient broth (NB) were supplied by Oxoid Ltd. The minimal medium (MM) was as described by Smith (I96I). Minimal agar (MA) was obtained by adding I $\cdot 5 \%(\mathrm{w} / \mathrm{v})$ Oxoid agar no. I to MM. MM was supplemented as required with the following: L-arginine, $20 \mu \mathrm{g} . / \mathrm{ml}$.; DL-ethionine, $1000 \mu \mathrm{g} . / \mathrm{ml}$.; $\alpha$-methyl-DL-methionine, 1000 $\mu \mathrm{g}$. $/ \mathrm{ml}$.; L-methionine, $20 \mu \mathrm{g} . / \mathrm{ml}$.; L-serine, $200 \mu \mathrm{g} .1$ $\mathrm{ml}$; uracil, $20 \mu \mathrm{g} . / \mathrm{ml}$.

Organisms. The nomenclature is that used by Sanderson (1967). Two Escherichia coli $\mathrm{F}^{\prime}$ donor strains were kindly provided by K. Brooks Low: a JC 1553 (argEhisleu metBlacmalxylstr-rrecAI) donor of KLF Io, an episome carrying the malB and met $B$ genes (Fig. I), and a JC I553 thy donor of KLF I6, an episome carrying the $\operatorname{ser} A$ and thy genes. All other strains were derived from Salmonella typhimurium strain LT2. A list of the regulatory mutants is given in Table $\mathrm{I}$, and Table 2 shows the derivation of multiple mutants.

Techniques. Cultures were grown at $37^{\circ}$ unless otherwise stated. The maintenance of stock cultures, and the propagation, assay and maintenance of transducing phage P 22 or its non-lysogenizing variant L 4 (Smith \& Levine, 1967; supplied by H. O. Smith) were as described by Smith (196I). Growth experiments in MM were essentially 
Table I. Methionine regulatory mutants of Salmonella typhimurium

All strains were derived from Salmonella typhimurium LT2. Tests of resistance to the methionine analogues $\alpha$-methyl-DL-methionine (AMM), DL-ethionine (ETH) and DLnorleucine (NOL), and detection of methionine excretion by cross-feeding of a methionine auxotroph, were as described by Lawrence et al. (1968). The nomenclature is that of Sanderson (1967).

\begin{tabular}{|c|c|c|c|c|c|}
\hline \multirow[b]{2}{*}{$\begin{array}{l}\text { Structural gene } \\
\text { mutations }\end{array}$} & \multirow{2}{*}{$\begin{array}{l}\text { Methionine } \\
\text { regulatory gene } \\
\text { mutations }\end{array}$} & \multicolumn{3}{|c|}{$\begin{array}{l}\text { Resistance }(R) \text { or } \\
\text { sensitivity }(S) \text { to }\end{array}$} & \multirow[b]{2}{*}{$\begin{array}{l}\text { Excretion of } \\
\text { methionine }\end{array}$} \\
\hline & & $\mathrm{AMM}$ & $\underbrace{}_{\text {ETH }}$ & NOL & \\
\hline $\arg F I I I$ & - & S & $\mathbf{S}$ & $\mathbf{S}$ & - \\
\hline $\arg F I I I$ & $\operatorname{met}_{713}$ & $\mathbf{S}$ & $\mathbf{R}$ & $S$ & + \\
\hline $\arg F I I I$ & met $J_{743}$ & $\mathbf{S}$ & $\mathbf{R}$ & $\mathrm{S}$ & + \\
\hline $\arg F I I I$ & met $K_{747}$ & $\mathbf{R}$ & $\mathrm{R}$ & $\mathbf{R}$ & + \\
\hline $\operatorname{ser} A I I$ & - & $\mathbf{S}$ & $\mathbf{S}$ & $\mathbf{S}$ & - \\
\hline $\operatorname{ser} A I I$ & $\operatorname{met}_{747}$ & $\mathrm{R}$ & $\mathrm{R}$ & $\mathbf{R}$ & + \\
\hline $\operatorname{ser} A I I$ & $\operatorname{met} K_{75 I}$ & $\mathrm{R}$ & $\mathrm{R}$ & $\mathbf{R}$ & - \\
\hline $\operatorname{ser} A I I$ & $m e t K 752$ & $\mathrm{R}$ & $\mathrm{R}$ & $\mathbf{R}$ & + \\
\hline $\operatorname{ser} A I_{3}$ & met $_{744}$ & $\mathbf{S}$ & $\mathbf{R}$ & $\mathrm{S}$ & + \\
\hline
\end{tabular}

Table 2. The derivation of Salmonella typhimurium multiple mutants

Spontaneous (spont) methionine regulatory mutants were obtained as colonies growing on MA containing ethionine (Lawrence et al. I968). $N$-methyl $N^{\prime}$-nitro $N$-nitrosoguanidine treatment (NG), conjugation (conj) and transduction (trans) were as described by Ayling \& Chater (1968). Temporary strain numbers are for use only in the context of this table, recipient numbers preceding those of donors in descriptions of crosses. Bracketed strains were used only in deriving strains and are not referred to in the text. A linkage map including the markers used is given in Fig. 1 .

\begin{tabular}{|c|c|c|}
\hline $\begin{array}{l}\text { Temporary } \\
\text { strain number }\end{array}$ & Genotype & $\begin{array}{l}\text { Mode of origin, } \\
\text { or source }\end{array}$ \\
\hline I & $\operatorname{argFIII}$ & J. D. Childs \\
\hline 2 & (argFIIIilv) & From I by NG \\
\hline 3 & (argFIIImet $B 406)$ & $2 \times 18($ conj $)$ \\
\hline 4 & $\operatorname{argFIIImetJ_{7}I_{3}}$ & $3 \times$ ro (trans) \\
\hline 5 & $\arg F_{I}$ I Imet $J_{743}$ & From I by spont. mutation \\
\hline 6 & $\operatorname{argFI}{ }^{\prime} I m e t K_{747}$ & $2 \times 21($ conj $)$ \\
\hline 7 & $(\operatorname{argFIIIrec-3OI})^{*}$ & From I by NG \\
\hline 8 & $\operatorname{argFIIIrec-30Ipy!*}$ & From 7 by $N G$ \\
\hline 9 & $(\operatorname{argFIIIser} A I 3)$ & $2 \times 20($ conj $)$ \\
\hline IO & $\left(\operatorname{met}_{713}\right)$ & D. A. Lawrence \\
\hline I I & $\operatorname{ser} A I I$ & D. A. Lawrence \\
\hline I 2 & serAI Imet $K_{747}$ & From I I by spont. mutation \\
\hline 13 & $\left(\operatorname{ser} A I_{3}\right)$ & K. E. Sanderson \\
\hline 14 & $\operatorname{ser} \mathrm{AI}_{3} \mathrm{met}_{744}$ & $9 \times \mathrm{I} 8(\mathrm{conj})$ \\
\hline 15 & $(\operatorname{ser} A 13 r e c-302)^{*}$ & From I 3 by NG \\
\hline 16 & serAI 3rec-302met-754* & From I 5 by $N G$ \\
\hline 17 & $\left(\operatorname{met}_{747}\right)$ & $12 \times$ wild-type $\mathbf{L T} 2$ (trans) \\
\hline 18 & (HfrAhis D23met B406) & J. D. Childs \\
\hline 19 & $\left(\mathrm{Hfr}_{3} \mathrm{ser} \mathrm{AI}_{3}\right)$ & K. E. Sanderson \\
\hline 20 & $\left(H f_{r} K_{3} \operatorname{ser} A_{13} h i s\right)$ & From 19 by $\mathrm{NG}$ \\
\hline $2 I$ & (HfrK3metK747his) & $20 \times 17$ (trans) \\
\hline
\end{tabular}

* Recombinant formation in conjugation and transduction was greatly reduced with rec-301 or -302 recipients, though $\mathrm{F}^{\prime}$ merodiploid formation was normal. The rec mutations also resulted in hypersensitivity to ultraviolet irradiation and, in the case of rec-30r, to NG (Chater, 1969). 
as described by Lawrence et al. (I968). Episome transfer was carried out by the spot method of Fink \& Roth (I968). $\mathrm{F}^{\prime}$ heterogenotes were purified by subculturing the crude isolates in selective MM to stationary phase, and spreading a $10^{-6}$ dilution on selective MA. After incubation of such plates for $48 \mathrm{~h}$., discrete colonies were obtained. Haploid segregants from heterogenote cultures were detected, after subculture in NB to stationary phase (sometimes followed by subculture in NB + acridine orange $(20 \mu \mathrm{g}$.) ml.; Hirota, 1960)), by spreading a suitable dilution on NA, incubating for $24 \mathrm{~h}$., and replicating to appropriately supplemented MA, so that auxotrophic segregants and prototrophic heterogenotes could be distinguished.

Assay of cystathionase activity. Late logarithmic phase MM cultures grown at $25^{\circ}$ in randomized positions in a shaking water-bath were harvested by centrifugation, washed in culture volumes of ro mM potassium phosphate buffer $(\mathrm{pH} 7 \cdot 4)$, and finally resuspended in the same buffer. The optical density of each suspension was measured at $650 \mathrm{~nm}$., and usually adjusted to $\mathrm{I} \cdot 5 \mathrm{units}$ ( $\mathrm{I}$ unit $=0.375 \mathrm{mg}$. dry wt $/ \mathrm{ml}$.), though less dense suspensions were sometimes used. Toluene was added (to I \% of the total volume), and the suspension emulsified using a Whirlimixer, prior to incubation at $30^{\circ}$ for $20 \mathrm{~min}$. Such suspensions were then used immediately, or after storage at $0^{\circ}$ for up to $2 \mathrm{~h}$. The method for assaying cystathionase activity was adapted from that of Rowbury \& Woods (I964) with cell-free extracts. Incubation was at $30^{\circ}$. The reaction mixture contained, in a final volume of $\mathrm{I} \mathrm{ml}$. ( $\mu$ moles): potassium phosphate buffer, $\mathrm{pH} 7.4$, I00; pyridoxal phosphate, 0.0025; DL-allocystathionine, I0; and toluene-treated cells, 0.04 to $0.3 \mathrm{mg}$. dry wt. Cystathionine was added to the preincubated mixture to start the reaction, which was stopped after measured time intervals of up to $40 \mathrm{~min}$. by the addition of $0.33 \mathrm{ml}$. of a $\mathrm{I} \%$ solution of 2,4 -dinitrophenylhydrazine in $2 \mathrm{M}-\mathrm{HCl}$. After a further $15 \mathrm{~min}$., $2 \mathrm{ml}$. of $2 \mathrm{M}-\mathrm{KOH}$ was added. The extinction at $445 \mathrm{~nm}$. was determined after Io min. had elapsed, against a blank from which both cystathionine and toluene-treated cells had been omitted. Corrections to this reading were made by subtraction of readings obtained with controls lacking, respectively, cystathionine and toluene-treated cells. Under the conditions of the assay I $\mu$ mole of pyruvate 2,4 -dinitrophenylhydrazone gave an extinction rate at $445 \mathrm{~nm}$. of $5^{\circ}$. The formation of pyruvate from cystathionine by toluene-treated cells proceeded at a constant rate for at least $40 \mathrm{~min}$. This rate was shown to be proportional to the quantity of cells added to the reaction mixture.

Assay of methionine permease activity. Cultures were grown overnight (with shaking) in $\mathrm{Io} \mathrm{ml}$. $\mathrm{MM}+0.4 \%$ glucose, then added to $40 \mathrm{ml}$. fresh medium and incubated for a further $75 \mathrm{~min}$. Chloramphenicol $(200 \mu \mathrm{g} . / \mathrm{ml}$.) was added, and incubation continued for $30 \mathrm{~min}$. The cells were then harvested by centrifugation, washed in $50 \mathrm{ml}$. ice-cold $\mathrm{MM}+$ glucose + chloramphenicol, and finally resuspended in $5 \mathrm{ml}$. of the same medium. The extinction at $650 \mathrm{~nm}$. of each suspension was determined, and the volume required to give a final concentration of $50 \mu \mathrm{g}$. dry $\mathrm{wt} / \mathrm{ml}$. was added to a $25 \mathrm{ml}$. beaker containing a suitable quantity of $\mathrm{MM}+$ glucose + chloramphenicol, in a shaking water-bath at $25^{\circ}$. After I min. 50 sec., shaking was stopped and aeration continued through the rest of the experiment by the operation of a spring-loaded syringe with its tip in the reaction mixture. Methyl-labelled $\left[{ }^{14} \mathrm{C}\right]$ methionine (Radiochemical Co., Amersham, Bucks.) (10.7 $\mu \mathrm{Ci} / \mu$ mole, final concentration $5 \mu \mathrm{M})$ was added $\mathrm{Io} \mathrm{sec}$. later, and $\mathrm{I} \mathrm{ml}$. samples removed by means of the syringe to Millipore filtration units so that filtration took place at $10,25,40,55$ and 70 sec. Filtration was 
immediately followed by washing twice with $5 \mathrm{ml}$. MM+glucose + chloramphenicol at room temperature. In all experiments, a final sample was taken into I $\mathrm{ml} .10 \%$ trichloroacetic acid at $85 \mathrm{sec}$. The insoluble material was filtered and washed twice with $5 \mathrm{ml}$. trichloroacetic acid. All filters were then dried under a lamp and added to $5 \mathrm{ml}$. of scintillation fluid (xylene Pop-op Ppo) prior to assaying in a liquid scintillation counter.

The method is based on that of Piperno \& Oxender (I968) as modified by P. D. Ayling \& E. S. Bridgeland (manuscript in preparation). I am indebted to Dr Ayling for his collaboration in the performance of these experiments.

\section{RESULTS}

\section{Dominance tests with metJ mutants}

The properties of KLF Io in Salmonella typhimurium. The episome to be used in the met $J$ dominance tests, KLF Io, was first transferred from its Escherichia coli JC 1553 host into Salmonella typhimurium argFII Irec-30I pyr. As the episome carried the arg $H$ gene (i.e. the $E$. coli homologue of $\arg F$ in $S$. typhimurium) but not the $p y r^{+}$allele, the required heterogenotes were selected on $\mathrm{MA}+$ uracil. The episome could then be freely transferred to further $S$. typhimurium $\arg F r I I$ recipients, selecting for prototrophic growth, without loss of efficiency due to restriction (Okada, Watanabe \& Miyake, 1968). KLF Io heterogenotes segregated frequent arginine-requiring organisms (Io to $50 \%$ ) when subcultured into NB. Of more than 300 such segregants from cultures of FI I ImetJ/argKLFio heterogenotes examined during this investigation none was ethionine-sensitive, showing that recombination between the episome and the host's chromosome was rare.

Ethionine sensitivity of metJ heterogenotes. Ethionine sensitivity was tested by streak tests on MA+ ethionine and by growth experiments in MM + ethionine. Typical results of the latter experiments (each of which was carried out at least twice) are shown in Fig. 2; essentially similar results were obtained from the streak tests. Possession of either of two mutations $m e t_{7} I_{3}$ and $J_{743}$ resulted in resistance of the haploid host cell to ethionine (Fig. $2 b, c$ ). When such cells were made heterozygous for met $J$ by the introduction of KLF IO, they became sensitive to the analogue (Fig. $2 f, g$ ). The degree of sensitivity was not the same in the two heterogenotes: $m e t J_{7} I_{3} / \mathrm{KLFI}_{10}$ was as sensitive as a wild-type (met $J^{+} /$met $^{+}$) homogenote (Fig. $2 e$ ), whereas met $J_{743} / \mathrm{KLF}_{\mathrm{IO}}$ was slightly more resistant.

The sensitivity of the two met $J / m^{2} J^{+}$strains could have reflected either dominance of met $^{+}$over met $J$, or some other, independent, effect on ethionine resistance of the presence of KLF IO. The latter possibility was unlikely, because the presence of KLF Io in the ethionine-resistant strain met $K_{747}$, in which the lesion resulting in resistance was located outside the region covered by the episome, did not result in ethionine sensitivity (Fig. $2 d, h$ ).

Repressibility of the methionine enzymes in metJ heterogenotes. Lawrence et al. (I968) showed that the ability of metJ and some met $K$ mutants to cross-feed a methionine-requiring strain in streak tests on MA resulted from constitutive synthesis of the methionine biosynthetic enzymes. Haploid strains possessing met $_{7} I_{3}$ or $J_{743}$ mutations gave such cross-feeding (Table 1 ). However, the introduction into these strains of $\mathrm{metJ}^{+}$, on the episome KLF I0, resulted in loss of the ability 
to cross-feed, while in control experiments the wild-type (met $\left.J^{+}\right)$failed to cross-feed, and a met $K_{747}$ (met $J^{+}$met $K$ ) strain succeeded in doing so, both with and without the episome. Thus repressibility of the methionine biosynthetic enzymes appeared to be dominant to their constitutive synthesis in met $J /$ met $^{+}{ }^{+}$heterogenotes. To confirm and measure this effect, one of the enzymes was assayed in the appropriate strains grown in the presence and absence of methionine. Cystathionase, the enzyme specified by metC (Fig. I), was selected because of the convenience of the assay method, but it had

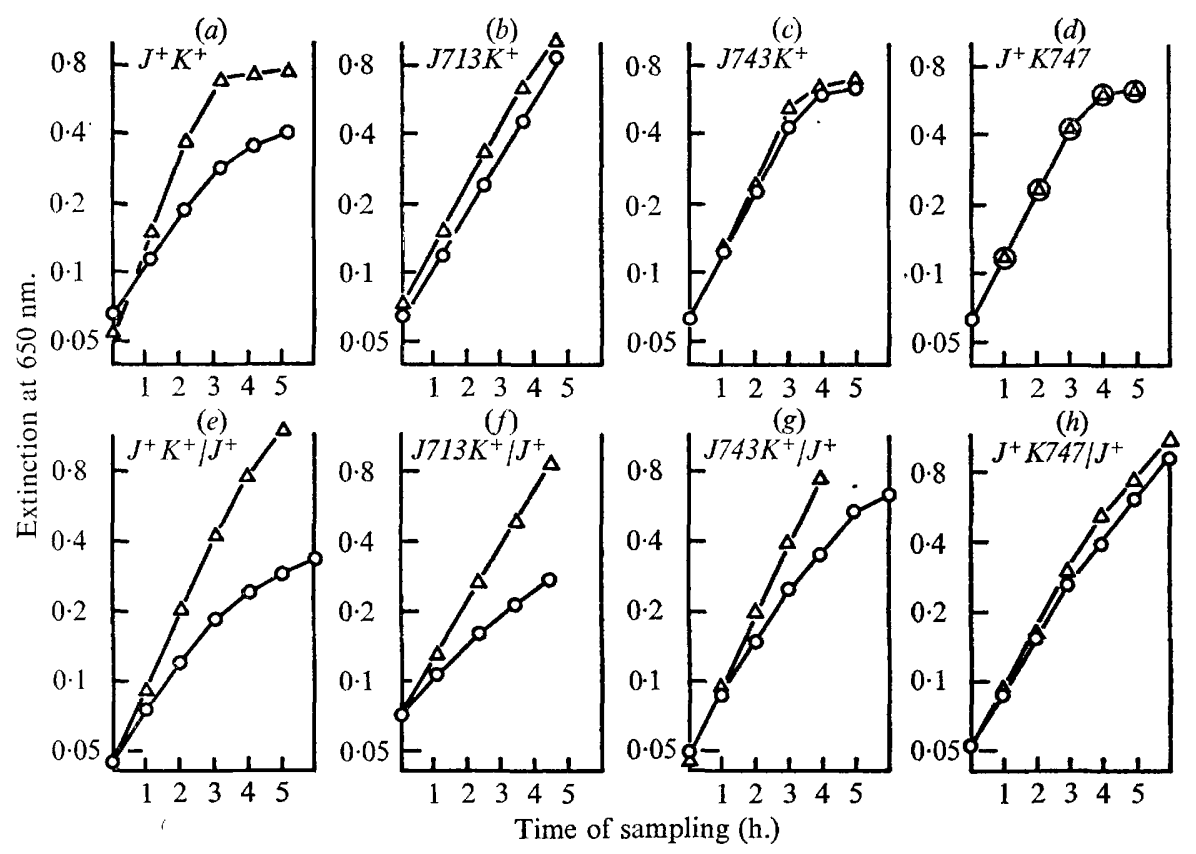

Fig. 2. Growth of met $J$ heterogenotes and control strains in the presence of ethionine. All the parental haploid strains had the argFrrI mutation (see Table I). Heterogenotes were obtained by transferring the Escherichia coli episome KLF Io (Fig. I) into these parental strains. Inocula were in the exponential phase of growth. Cultures were grown in $M M(\triangle)$ and $\mathrm{MM}+$ ethionine, $1000 \mu \mathrm{g} . / \mathrm{ml}$. (O). The relevant genotypes (i.e. with respect to met $J$ and $K$ ) are indicated on the graphs: where merodiploids were used, relevant episomal markers are given after a diagonal stroke.

the disadvantage of relatively low sensitivity to regulation. For this reason, the experiments were carried out with cultures grown in groupings that permitted appropriate analyses of variance to be made on results obtained in essentially identical conditions. The results of these experiments are given in Table 3. Before analysis, all results were transformed into logarithms to ensure that, for example, a twofold difference between untransformed readings was given equal weighting in the analysis whatever the absolute value of the readings.

In Expts $I$ and 2 the activity of cystathionase in the metJ/met $J^{+}$heterogenotes was compared with the mean of the values for the wild-type and mutant haploids. In the absence of dominance of either met $J^{-}$or met $^{+}$, no significant difference would have been expected. However, met $J_{7 I 3 / \mathrm{KLF}}$ I0 $\left(J / J^{+}\right)$closely resembled the haploid wildtype $\left(J^{+}\right)$, and differed significantly $(P=\mathrm{I}$ to $0 . \mathrm{I} \%)$ from the mean of the two haploids 
(Expt $\mathrm{I}$ ). This suggested that met ${ }_{71} 3$ was completely recessive to the episomal met $^{+}$. In contrast, the second $J / J^{+}$strain (met $J_{743} / \mathrm{KLF} 10$; Expt 2 ) differed only marginally $(P=10$ to $5 \%)$ from the mean of the two haploids, and thus met $J 743$ appeared not to be fully recessive to $m e t J^{+}$. In confirmation of this, the $m e t J_{743} / \mathrm{KLF}$ io heterogenote was found to differ significantly $\left(P=5\right.$ to $\mathrm{I} \%$ ) from a $J^{+} / J^{+}$strain (Expt 3 ). Finally, the effect of KLF ro on the regulation of cystathionase synthesis was tested in a wildtype $\left(\right.$ met $\mathrm{J}^{+}$met $\left.\mathrm{K}^{+}\right)$strain and the constitutive mutant met $K_{747}\left(\mathrm{~J}^{+} \mathrm{K}\right)$ in which the regulatory mutation was situated outside the region duplicated by the episome (Expt 4). No significant effect of the episome was detected in these strains, showing that the effect of KLF Io on regulation observed in met $J$ mutants was due to a true dominance effect, and not to some other, nonspecific, regulatory effect of the episome.

\title{
Table 3. Cystathionase activity in metJ heterogenotes and control strains
}

\begin{abstract}
Each value is the mean of two or more replicate experiments in which cystathionase activity was determined by the toluene-treated cell procedure described in Methods. The activity is given as $\mu$ moles pyruvate produced from cystathionine in I h. by I mg. (dry wt) of cells, at $30^{\circ}$. All strains possessed a chromosomal $\operatorname{argFIII}$ mutation which was expressed only in haploid strains. Arginine $(20 \mu \mathrm{g} . / \mathrm{ml}$.) was therefore added to haploid, but not to partially diploid cultures. In the column 'Pertinent genotype', chromosomal methionine regulatory gene mutations precede the diagonal stroke, and regulatory genes carried by the episome KLF ro follow it. Arginine-requiring segregants were obtained from all heterogenote cultures used, following subculture into nutrient broth, proving that the parental cultures had been heterogenotic.
\end{abstract}

The results of statistical analysis of these experiments are given in the text.

\begin{tabular}{|c|c|c|c|c|c|c|}
\hline \multirow[b]{2}{*}{$\begin{array}{c}\text { Experi- } \\
\text { ment }\end{array}$} & \multirow[b]{2}{*}{$\begin{array}{l}\text { Regulatory } \\
\text { mutations }\end{array}$} & \multirow[b]{2}{*}{$\begin{array}{l}\text { Possession } \\
\text { of KLF Io }\end{array}$} & \multirow[b]{2}{*}{$\begin{array}{l}\text { Pertinent } \\
\text { genotype }\end{array}$} & \multicolumn{2}{|c|}{ Cystathionase activity } & \multirow[b]{2}{*}{$\begin{array}{l}\text { Number of } \\
\text { replicates }\end{array}$} \\
\hline & & & & $\begin{array}{c}\text { Methionine } \\
\text { absent from } \\
\text { growth medium }\end{array}$ & $\begin{array}{l}\text { Io mM-methionine } \\
\text { present in } \\
\text { growth medium }\end{array}$ & \\
\hline I & $\begin{array}{l}\text { None } \\
\text { met } J_{713} \\
\text { met } J_{7} I_{3}\end{array}$ & $\begin{array}{l}- \\
- \\
+\end{array}$ & $\begin{array}{l}J^{+} \\
J \\
J / J^{+}\end{array}$ & $\begin{array}{l}0.83 \\
I .92 \\
0.85\end{array}$ & $\left.\begin{array}{l}0.45 \\
I .79 \\
0.45\end{array}\right\}$ & 2 \\
\hline 2 & $\begin{array}{l}\text { None } \\
\text { met } J_{743} \\
\text { met } J_{743}\end{array}$ & $\begin{array}{l}- \\
- \\
+\end{array}$ & $\begin{array}{l}J^{+} \\
J \\
J / J^{+}\end{array}$ & $\begin{array}{l}0.9 I \\
I \cdot 4 I \\
0.9 I\end{array}$ & $\begin{array}{l}0.5 I \\
I .49 \\
0.69\end{array}$ & 3 \\
\hline 3 & $\begin{array}{l}\text { None } \\
\text { met } J 743\end{array}$ & $\begin{array}{l}+ \\
+\end{array}$ & $\begin{array}{l}J^{+} / J^{+} \\
J / J^{+}\end{array}$ & $\begin{array}{l}0.64 \\
0.85\end{array}$ & $\begin{array}{l}0.37 \\
0.61\end{array}$ & 2 \\
\hline 4 & $\begin{array}{l}\text { None } \\
\text { None } \\
\text { met } K 747 \\
\text { metK } 747\end{array}$ & $\begin{array}{l}\overline{+} \\
\overline{+}\end{array}$ & $\begin{array}{l}J^{+} K^{+} \\
J^{+} K^{+} / J^{+} \\
J^{+} K \\
J^{+} K \mid J^{+}\end{array}$ & $\begin{array}{l}0.6 I \\
0.53 \\
I .36 \\
I \cdot 0 I\end{array}$ & $\begin{array}{l}0.28 \\
0.21 \\
I .09 \\
I .01\end{array}$ & 2 \\
\hline
\end{tabular}

\section{Dominance tests with metK mutants}

The properties of KLF I6 in Salmonella typhimurium. As the episome KLF I6 extended from thy on one side of ser $A$ to a point well to the other side (Fig. I; K. Brooks Low, personal communication), it was considered that it might carry the met $K$ gene (met $K$ and $\operatorname{ser} A$ being cotransduced; Lawrence et al. 1968), and therefore be suitable for use in $m e t K$ dominance tests. The episome was transferred from its Escherichia coli JC I 553 thy host into Salmonella typhimurium serAI 3rec-302met-754, with selection of the required heterogenotes on MA + methionine. One of these was purified and used for transfer of KLF I 6 to further $S$. typhimurium ser $A$ recipients, the resulting heterogenotes being selected as prototrophs. KLF I 6 was found to be more stable than 
KLF Io in $S$. typhimurium hosts: fewer than I \% serine-requiring segregants were usually obtained after growth of KLF I6 heterogenotes in NB. However, acridine orange treatment (Hirota, 1960) increased the proportion of segregants. No ethioninesensitive recombinants were detected among more than 100 serine-requiring segregants from various metK/KLF I 6 cultures, so that, as with KLF Io heterogenotes, recombination between the episome and the host's chromosome was rare.

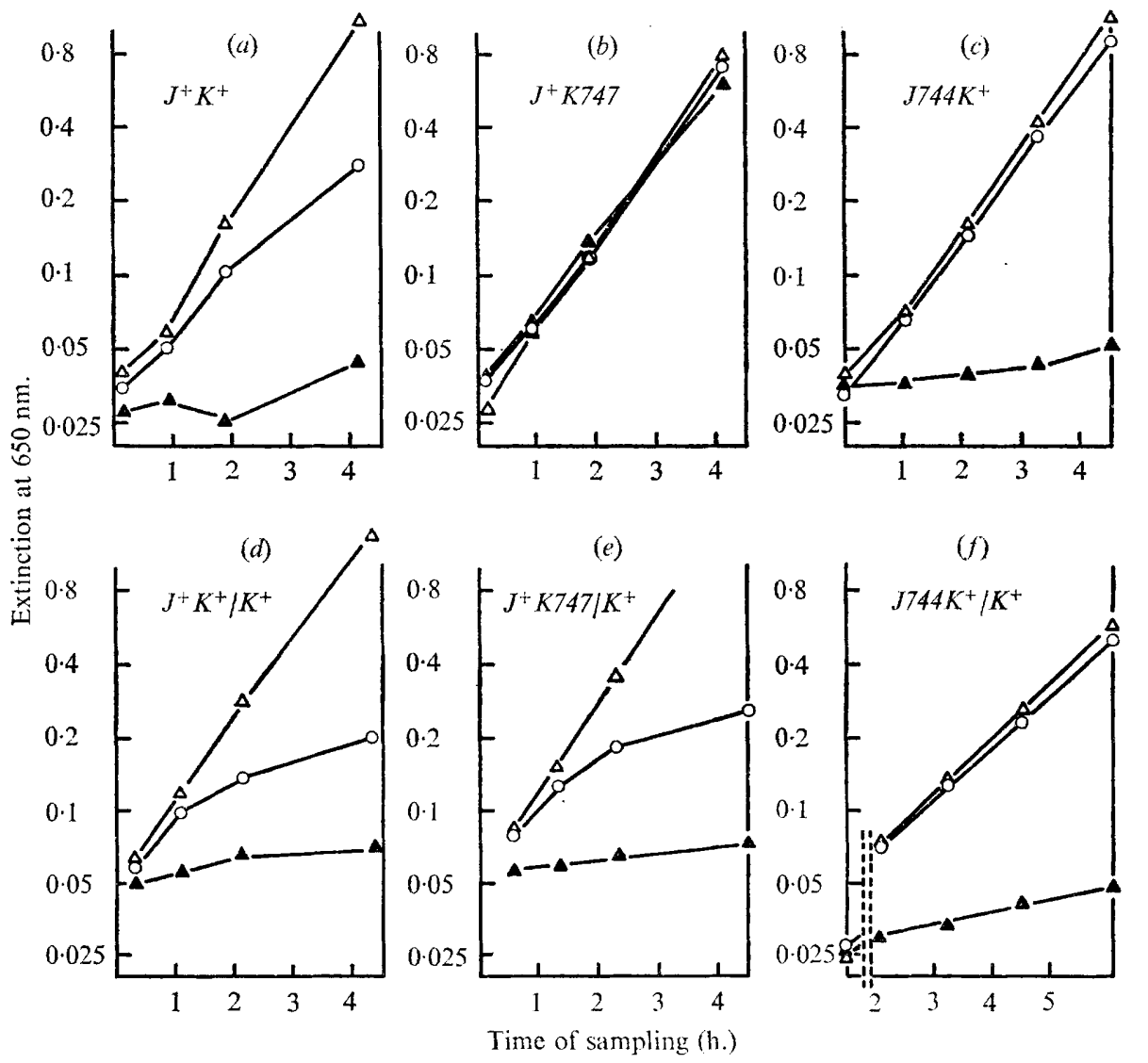

Fig. 3. Growth of met $K$ heterogenote and control strains in the presence of methionine analogues. All the parental haploid strains possessed ser $A$ mutations (see Table I). Heterogenotes were obtained by transferring the Escherichia coli episome KLF 16 (Fig. I) into these parental strains. Inocula were in the exponential phase of growth. Cultures were grown in $\mathrm{MM}(\triangle), \mathrm{MM}+$ ethionine, $1000 \mu \mathrm{g} \cdot / \mathrm{ml}$. (O), and $\mathrm{MM}+\alpha$-methylmethionine, $1000 \mu \mathrm{g} . / \mathrm{ml}$. ( $\Delta)$. The relevant genotypes (i.e. with respect to met $J$ and $K$ ) are indicated on the graphs: where merodiploids were used, relevant episomal markers are given after a diagonal stroke.

Methionine analogue sensitivity of metK heterogenotes. As with metJ heterogenotes, the results of streak tests of the analogue resistance of met $K$ heterogenotes were confirmed by growth experiments in liquid media. Examples of the latter results are shown in Fig. 3. Possession of any of the three mutations met $K_{747}, K_{75 I}$ and $K_{752}$ by a haploid strain resulted in its resistance to $\alpha$-methylmethionine and ethionine (Fig. $3 b$ ). The introduction into these strains of $m e t K^{+}$, on KLF I6 (Fig. $3 e$ ), made them as 
sensitive to both analogues as the wild-type $\left(\right.$ met $\left.K^{+}\right)$haploid and homogenote (Fig. $3 a, d)$. The absence of a nonspecific effect of KLF 16 on analogue resistance was confirmed (Fig. $3 c, f$ ) by the observation that ethionine resistance in a met $J$ mutant was independent of the presence or absence of the episome, which did not cover the met $J$ region (Fig. I). Thus the analogue sensitivity observed in $m e t K /$ met $^{+}$heterogenotes reflected a true dominance of the wild-type over the mutant alleles.

Repressibility of the methionine enzymes in met $K$ heterogenotes. Cross-feeding tests showed that the possession of KLF 16 by met $K_{747}$ and $K_{752}$ mutants prevented the excretion of methionine observed in the parental haploid strains, while excretion by strain met $_{744}$ was unaffected by possession of the episome. Thus repressibility of the methionine biosynthetic enzymes was apparently dominant to their constitutive synthesis in met $K /$ met $^{+}$heterogenotes. As in the previous experiments with met $J$

Table 4. Cystathionase activity in metK heterogenotes and control strains

Each value is the mean of two replicate experiments in which cystathionase activity was determined by the toluene-treated cell procedure described in Methods. The unit of cystathionase activity is given in Table 3 . All strains possessed a chromosomal ser $A$ mutation which was expressed only in haploid strains. Serine $(200 \mu \mathrm{g} . / \mathrm{ml}$.) was therefore added to haploid, but not to partially diploid, cultures. In the column headed 'Pertinent genotype', chromosomal methionine regulatory gene mutations precede the diagonal stroke, and regulatory genes carried by the episome KLF I 6 follow it. Serine-requiring segregants were obtained from all heterogenote cultures used, following subculture into nutrient broth containing acridine orange (Hirota, 1960). This proved that the parental cultures had been heterogenotic.

The results of statistical analysis of these experiments are given in the text.

\begin{tabular}{|c|c|c|c|c|c|}
\hline \multirow[b]{2}{*}{$\begin{array}{c}\text { Experi- } \\
\text { ment }\end{array}$} & \multirow[b]{2}{*}{$\begin{array}{l}\text { Regulatory } \\
\text { mutations }\end{array}$} & \multirow[b]{2}{*}{$\begin{array}{l}\text { Possession of } \\
\text { KLF } 16\end{array}$} & \multirow[b]{2}{*}{$\begin{array}{l}\text { Pertinent } \\
\text { genotype }\end{array}$} & \multicolumn{2}{|c|}{ Cystathionase activity } \\
\hline & & & & $\begin{array}{l}\text { Methionine absent } \\
\text { from culture } \\
\text { medium }\end{array}$ & $\begin{array}{l}\text { Io mM-methionine } \\
\text { in culture } \\
\text { medium }\end{array}$ \\
\hline I & $\begin{array}{l}\text { None } \\
\text { metK } 747 \\
\text { metK } 747\end{array}$ & $\overline{-}$ & $\begin{array}{l}K^{+} \\
K \\
K / K^{+}\end{array}$ & $\begin{array}{l}0.75 \\
1 \cdot 36 \\
2 \cdot 56\end{array}$ & $\begin{array}{l}0.37 \\
I \cdot 15 \\
I \cdot 25\end{array}$ \\
\hline 2 & $\begin{array}{l}\text { None } \\
\text { metK75I } \\
m e t K_{75 I}\end{array}$ & $\overline{-}$ & $\begin{array}{l}K^{+} \\
K \\
K / K^{+}\end{array}$ & $\begin{array}{l}0.32 \\
0.96 \\
2.03\end{array}$ & $\begin{array}{l}0.16 \\
0.35 \\
0.72\end{array}$ \\
\hline 3 & $\begin{array}{l}\text { None } \\
m e t K_{752} \\
m e t K_{752}\end{array}$ & $\begin{array}{l}- \\
+\end{array}$ & $\begin{array}{l}K^{+} \\
K \\
K / K^{+}\end{array}$ & $\begin{array}{l}0.56 \\
1 \cdot 47 \\
2 \cdot 18\end{array}$ & $\begin{array}{l}0 \cdot 16 \\
I \cdot 28 \\
I \cdot 04\end{array}$ \\
\hline 4 & $\begin{array}{l}\text { None } \\
m e t K 747\end{array}$ & $\begin{array}{l}+ \\
+\end{array}$ & $\begin{array}{l}K^{+} / K^{+} \\
K / K^{+}\end{array}$ & $\begin{array}{l}2 \cdot 35 \\
2 \cdot 18\end{array}$ & $\begin{array}{l}0.93 \\
0.75\end{array}$ \\
\hline 5 & $\begin{array}{l}\text { None } \\
\text { None } \\
\text { met } J_{744} \\
\text { met } J_{744}\end{array}$ & $\begin{array}{l}- \\
+ \\
\bar{t}\end{array}$ & $\begin{array}{l}J^{+} K^{+} \\
J^{+} K^{+} / K^{+} \\
J K^{+} \\
J K^{+} / K^{+}\end{array}$ & $\begin{array}{r}0.53 \\
2 \cdot 42 \\
2 \cdot 24 \\
12.05\end{array}$ & $\begin{array}{l}0 \cdot 24 \\
I \cdot 01 \\
I \cdot 60 \\
9 \cdot 30\end{array}$ \\
\hline
\end{tabular}

heterogenotes, this effect was examined quantitatively by assaying cystathionase activity in the appropriate strains grown in the presence and absence of methionine (Table 4). The experiments were again designed to permit statistical analysis of the results.

In Expts I to 3 three $m e t K / m e t K^{+}$heterogenotes were compared with the wild-type $\left(m e t K^{+}\right)$and the appropriate $m e t K$ haploid strain. One of the strains (metK $75 I$ ) was 
of the nonexcreting type (Table I), and this was the only one of the three met $K$ mutants to show repressibility in the haploid state. However, all three $K / K^{+}$heterogenotes showed repressibility, but in each case the total activity was several times greater than in the haploid wild type (met $\left.K^{+}\right)$and was indeed significantly greater in two cases than in the met $K$ haploid strain $\left(P=5 \%\right.$ with met $K_{747},<0 \cdot I \%$ with $K_{75 I}$, in nonorthogonal comparisons).

A simple hypothesis to explain these results was that KLF I 6 carried the met $C$ gene, leading to a gene dosage effect on cystathionase activity in the heterogenotes. To test this, strain serAr3rec-302met-754/KLF I 6 was crossed with the mutant metCro4 (Smith \& Childs, I966) on MA. Confluent growth was obtained. A purified subculture of this prototrophic growth was treated with acridine orange, and methionine-requiring segregants were obtained, confirming that KLF I 6 carried the met $C$ gene. In addition, the cystathionase activities of metCI04/KLF I $6\left(C / C^{+}\right)$and the wild-type homogenote $\left(C^{+} / C^{+}\right)$were compared. The values obtained for cells grown in the absence and presence, respectively, of Io mM methionine were: $\mathrm{I} \cdot 23$ and $0.5 \mathrm{I}$ units for $C / C^{+}$, and 2.05 and 0.80 units for $C^{+} / C^{+}$. The two strains differed significantly $(P=\mathrm{I}$ to $0.1 \%)$, and by about the amount which would be predicted if the $C / C^{+}$strain possessed one copy fewer of the metC gene than did the $C^{+} / C^{+}$strain. Clearly, then, a gene dosage effect was responsible for the high activities found in KLF I 6 heterogenotes. (It was not possible to estimate the number of copies of the episome per chromosome from the increase in cystathionase activity when KLF I 6 was present, because the enzymes from Escherichia coli and Salmonella typhimurium may differ in their repressibility and catalytic activity.)

The activity of cystathionase observed in the latter experiment with the wild-type homogenote $\left(\right.$ met $^{+} K^{+} / C^{+} K^{+}$) was very similar to that of the $K / K^{+}$strains (Table 4, Expts I to 3 ). A further experiment confirmed this: no significant difference was detected between $m e t K 747 /$ KLF I6 $\left(K / K^{+}\right)$and the $K^{+} / K^{+}$strain (Table 4 , Expt 4 ). Thus the $m e t K$ phenotype was not expressed in a strain possessing KLF 16. Finally, the effect of KLF I6 was examined in a normally regulated $\left(J^{+} K^{+}\right)$strain, and a met $J\left(J K^{+}\right)$ mutant in which constitutivity resulted from a mutation outside the diploid region (Table 4, Expt 5). The effect of the met $J$ mutation was highly significant $(P<0 \cdot 1 \%)$, regardless of the presence of the episome; similarly, the effect of the episome was also highly significant $(P<0.1 \%)$, regardless of which met $J$ allele was present. However, no significant difference could be detected between the effect of the episome on the two strains $\left(J^{+} K^{+}\right.$and $\left.J K^{+}\right)$: in each case it caused four or five times more cystathionase activity than was found in the corresponding haploid, due to the met $C$ gene dosage effect. Thus KLF 16 affected the regulation of cystathionase synthesis only in constitutive met $K$ mutants. This specific effect of the episome could only be interpreted to mean that $m e t K^{+}$was dominant to $\operatorname{met} K$.

The absence of effects of met $K$ mutation and met $K$ gene dosage on the rate of methionine uptake by cell suspensions

Lawrence et al. (1968) found that growing cultures of met $K$ mutants incorporated less radioactivity from ${ }^{14} \mathrm{C}$-labelled ethionine or methionine, measured over $30 \mathrm{~min}$. intervals, than did met $J$ or wild-type strains. This observation, coupled with the crossresistance of met $K$ mutants to three methionine analogues that all inhibit the growth of Salmonella typhimurium in different ways, indicated that a methionine uptake 
system (permease) might be defective in met $K$ mutants. A permease specific for methionine has been detected in Escherichia coli ( $K_{m}$ (methionine), $2 \cdot 27 \pm 0.39 \mu \mathrm{M}$; Piperno \& Oxender, I968), and preliminary results (P. D. Ayling \& E. S. Bridgeland, personal communication) indicate that a transport system having a rather similar $K_{m}$ (methionine) also exists in $S$. typhimurium. Therefore any gross differences in the rate of methionine uptake between $S$. typhimurium strains should have been revealed by measuring the initial rate at which cells incorporated radioactivity from ${ }^{14} \mathrm{C}$-labelled methionine at an extracellular concentration of $5 \mu \mathrm{M}$, i.e. above the $K_{m}$ value. This method was used not only to detect differences between wild-type and met $K$ strains, but also to test the effect of met $K$ gene dosage on the rate of uptake. This was undertaken following the observation of Ames \& Roth (1968) that the presence of an episome

\title{
Table 5. The effects of metK mutation and gene dosage on the rate of uptake of $\left[{ }^{14} \mathrm{C}\right]$-L-methionine by cell suspensions
}

\begin{abstract}
Uptake of radioactivity by cells was measured as described in Methods, at $15 \mathrm{sec}$. intervals during the first $75 \mathrm{sec}$. after addition of $\left[{ }^{14} \mathrm{C}\right]-\mathrm{L}$-methionine to cell suspensions maintained at $25^{\circ}$. The rates of uptake were calculated from these data by the method of least squares. In each experiment, determinations were made with all four strains, so that valid comparisons could be made between strains.
\end{abstract}

\begin{tabular}{|c|c|c|c|c|c|}
\hline \multirow[b]{2}{*}{ Strain } & \multirow{2}{*}{$\begin{array}{l}\text { Pertinent } \\
\text { genotype }\end{array}$} & \multicolumn{4}{|c|}{$\begin{array}{l}\text { Rate of uptake of }\left[{ }^{14} \mathrm{C}\right]-\mathrm{L} \text {-methionine } \\
\text { (nmoles/mg. dry wt cells/min.) }\end{array}$} \\
\hline & & Expt I & Expt 2 & Expt 3 & Mean \\
\hline $\operatorname{ser} A I I$ & $\operatorname{met} K^{+}$ & 0.74 & $I \cdot 3 I$ & 0.83 & 0.96 \\
\hline serAI ImetK 752 & $\operatorname{met} K$ & 0.52 & $I \cdot 36$ & 0.85 & 0.91 \\
\hline $\operatorname{ser} A I I / \mathrm{KLF}$ I 6 & $\operatorname{met} K^{+} / K^{+}$ & 0.30 & $I \cdot 22$ & 0.82 & $0 \cdot 78$ \\
\hline ser $A_{1}$ Imet $K 752 / \mathrm{KLF}_{1} 6$ & $m e t K / K^{+}$ & 0.26 & I.09 & $0.8 \mathrm{I}$ & 0.72 \\
\hline
\end{tabular}

carrying the histidine permease gene resulted in a two- to threefold increase in the rate of histidine uptake by $S$. typhimurium. Thus if met $K$ specified methionine permease, the presence of KLF I6 (which carried $m e t K^{+}$) in a cell should have resulted in a twoto threefold increase in the rate of methionine uptake. (It is assumed that the $V_{\max }$ of the $E$. coli and $S$. typhimurium permeases is the same; this appears to be so for histidine permease (Ames \& Roth, 1968), and unpublished preliminary results obtained by P. D. Ayling and E. S. Bridgeland suggest that it is also true for methionine permease.) Triplicate experiments were therefore carried out with $m e t K^{+}, K 752, K^{+} / K^{+}$ and $K_{752} / K^{+}$strains (in collaboration with Dr P. D. Ayling). The results are given in Table 5. Although the absolute rates of uptake varied between experiments, it was clear that the rate of uptake was neither decreased by metK mutations nor increased when several copies of the met $K$ gene were present (i.e. in KLF I 6 merodiploids): indeed, the presence of KLF 16 appeared slightly to reduce the rate of uptake, though this effect was not statistically significant. It was concluded that the met $K$ gene did not specify a high affinity methionine permease, though the possibility that it could specify a low affinity one having a $K_{m}$ (methionine) greater than $5 \mu$ m was not excluded by these results. 


\section{DISCUSSION}

To what was previously known about met $J$ and $K$ mutants from the work of Lawrence et al. (1968) (see Introduction) it can now be added that representative mutant alleles of both loci were recessive to the respective wild-type alleles derived from Escherichia coli (Fig. 2, 3; Tables 3, 4).

The complete dominance of met $J^{+}$to the met ${ }_{713}$ allele indicated that the met $J^{+}$ product was active, and the metJ7I3 product inactive. That the gene product is a rather large molecule is suggested by the similarity in the lengths of the met $B$ and met $J$ genes, deduced from the finding that the variation in cotransduction frequencies of various mutations in the two genes with particular met $F$ mutations was similar (met $B$ $m_{e t} F_{31}, 2 \mathrm{I} \cdot 6$ to $34 \cdot \mathrm{I} \%$; Smith, I96I : metJ-metF96, 3 I to $52 \%$; Lawrence et al. I968): since the molecular weight of the met $B$ polypeptide (the subunit of cystathionine- $\gamma-$ synthetase) is about 40,000 daltons (Kaplan \& Flavin, I966), the met $J$ gene product is likely to be comparable in size. More direct evidence that the met $J$ gene product is indeed a protein has been provided by the recent isolation and identification of a metJ mutant suppressible by nonsense suppressors (A. J. Minson, personal communication).

At this point it is suggested that the metJ protein may be an apo-repressor of methionine synthesis. If so, the observation that the $\operatorname{met}_{743}$ allele, unlike $\operatorname{met}_{7 I_{3}}$, was not completely recessive to met $^{+}$(Fig. 2; Table 3), could be explained if the met $J$ product normally forms an oligomeric protein, in which case inactive mixed protein molecules containing mutant and wild-type subunits might have formed in the met $J_{743}$ | KLF io heterogenote. Thus the met $J$ gene product, if an apo-repressor, may resemble the lac apo-repressor of Escherichia coli in being an oligomer of high molecular weight (Muller-Hill, Crapo \& Gilbert, I968).

Recently, evidence that met $J$ specifies an apo-repressor has been obtained with a strain carrying a met $J$ mutation isolated by $\mathrm{D}$. A. Lawrence (unpublished) as a suppressor of a methionine auxotroph. In four determinations, this strain consistently gave very similar, partially derepressed cystathionase activity whether grown in the presence or absence of methionine (I0 $\mathrm{mM}$ ) (mean values, 0.56 and 0.63 units, respectively: Chater, 1969). It is difficult to envisage any explanation for this observation other than that in this strain the met $J$ product is a methionine apo-repressor whose conformation is unaffected by the presence of co-repressor, but which has some regulatory activity.

Ethionine inhibits the growth of bacteria by replacing methionine in protein synthesis (Spizek \& Janecek, 1969): it has no effect on $S$-adenosylmethionine synthesis (Cox \& Smith, 1969; Gross, 1969) and little effect on the activity of the methionine first enzyme (D. A. Lawrence, personal communication). Thus the ethione resistance of met $J$ mutants is probably the result of reduced incorporation of the analogue into proteins, attributable to the high intracellular methionine level.

The complete dominance of $m e t K^{+}$to the three $m e t K$ mutations tested indicated that the $m e t K^{+}$allele produced active, and the met $K$ mutant alleles inactive, product, with respect both to methionine analogue resistance and (where relevant) to regulation of methionine synthesis. This eliminated a positive role for the met $K$ product in the regulation of methionine synthesis. We may also be certain that the met $K$ mutations did not result in the acquisition of novel properties by the mutant gene product such 
that the methionine analogues were actively prevented from reaching their sites of inhibition. The resistance of met $K$ mutants to $\alpha$-methylmethionine, which acts specifically by inhibiting the activity of the methionine first enzyme (Schlesinger, 1967; Rowbury, 1968), could not have been the result of an altered component of the first enzyme, because $\alpha$-methylmethionine resistance would then have been dominant to sensitivity; moreover, this enzyme was sensitive to feedback inhibition by methionine in a $m e t K$ strain (Chater \& Rowbury, 1970).

The possibility that the $m e t K$ phenotype might result from an altered specificity or activity of methionine permease was eliminated by the finding that the rate of uptake of radioactive methionine was not influenced by met $K$ mutation or by changes in met $K$ gene dosage. This conclusion has recently been confirmed by the identification of a gene specifying methionine permease, which is located far from met $K$ on the linkage map (P. D. Ayling \& E. S. Bridgeland, personal communication).

Lawrence et al. (1968) were able to reject the possibility that the met $K$ gene product was an apo-repressor; and Gross \& Rowbury (1969) showed that methionyl-tRNA was unlikely to have any effect on regulation, while methionyl-tRNA synthetase was specified by the met $G$ gene. Thus conventional explanations for the met $K$ phenotype all appear inadequate, and it is necessary to look for a feature of methionine biosynthesis that is not shared by other well-established biosynthetic systems. The most obvious such feature is the role of methionine as the immediate precursor of $S$-adenosylmethionine, which is the universal donor of methyl groups in transmethylation reactions (Cantoni, 1965). $S$-Adenosylmethionine is known to be involved in feedback inhibition of the first enzyme of methionine biosynthesis in Escherichia coli (Lee, Ravel \& Shive, 1966) and Salmonella typhimurium (D. A. Lawrence, unpublished data); it is reasonable to suppose that it might also be involved in repression. $S$-Adenosylmethionine deficiency would then be expected to cause release from both feedback inhibition and repression, which might in turn result in the resistance to both $\alpha$-methylmethionine and ethionine which is one of the features of the met $K$ phenotype. The release from control of methionine biosynthesis would be most marked in strains with the most serious $S$-adenosylmethionine deficiencies, and such strains would also be expected to be somewhat slow-growing. Methionine-excreting met $K$ strains may illustrate this situation.

Some difficulties arise in the application of this hypothesis to met $K$ strains. Chater \& Rowbury (1970) have demonstrated that feedback inhibition by methionine occurred in a met $K$ strain, though it could be argued that sufficient methionine was accumulated by the cells in the conditions of the experiment to overcome a $K_{m}$ barrier to $S$-adenosylmethionine synthesis. Secondly, A. J. Minson (personal communication) has obtained viable met $K$ mutants suppressible by nonsense suppressors: although this is evidence that the metK gene product is a protein, it suggests that the function of the protein is not indispensable, as it would be expected to be if it were required to maintain a pool of $S$-adenosylmethionine.

Thus our present working hypothesis may be summarized as follows: the central factor in regulating methionine biosynthesis is the intracellular level of $S$-adenosylmethionine, which is dependent upon the activity of the met $K$ gene product (on the simplest model, this would be the enzyme $S$-adenosylmethionine synthetase). $S$-Adenosylmethionine participates both in feedback inhibition, by interaction with the enzyme homoserine- $O$-transsuccinylase, and in repression, by activating a (possibly oligomeric) 
protein apo-repressor coded for by the met $J$ gene. The active repressor acts in an unspecified way to reduce further synthesis of the enzymes of methionine synthesis.

A recent report by Green, Su \& Holloway (1970) describes $S$-adenosylmethionine synthetase deficient mutants of Escherichia coli which were ethionine-resistant, and possessed high levels both of the methionine biosynthetic enzymes and of methionine. No further data were presented that would permit comparison of the $E$. coli mutants with the known kinds of ethionine-resistant mutants of Salmonella typhimurium (Lawrence et al. 1968).

Some interesting incidental points arise from the use of $\mathrm{F}^{\prime}$ factors derived from Escherichia coli in this study. The rarity of recombination observed between the episomes and the chromosomes of the Salmonella typhimurium host cells suggested the absence of fine structure homology of the two types of DNA. Despite this, the $E$. coli regulatory elements efficiently controlled the expression of $S$. typhimurium genes. This is therefore another example of the evolutionary preservation of those parts of proteins concerned with quaternary interactions (Balbinder, I964; Ito, I969). Similar conclusions may be drawn from the work of Fink \& Roth (I968). Finally, the regulation of methionine synthesis in $E$. coli appears to be similar to that in $S$. typhimurium.

This work, most of which was included in a doctoral thesis submitted to Birmingham University in May 1969, was supported by a Science Research Council Studentship. The critical interest shown throughout by Dr D. A. Smith and Dr P. D. Ayling, and the guidance of Dr B. W. Barnes in statistics and of Dr E. S. Bridgeland and Dr T. S. Gross in biochemical techniques, are gratefully acknowledged.

\section{REFERENCES}

Ames, G. F. \& Roth, J. R. (1968). Histidine and aromatic permeases of Salmonella typhimurium. Journal of Bacteriology 96, $1742-1749$.

Ayling, P. D. \& Chater, K. F. (I968). The sequence of four structural and two regulatory methionine genes in the Salmonella typhimurium linkage map. Genetical Research 12, 34I-354.

BALBINDER, E. (I964). Intergeneric complementation between A and B components of bacterial tryptophan synthetases. Biochemical and Biophysical Research Communications 17, 770-774.

Cantoni, G. L. (1965). S-Adenosylmethionine revisited. In Transmethylation and Methionine Biosynthesis, p. 21. Edited by S. K. Shapiro \& F. Schlenk. University of Chicago Press.

CHATER, K. F. (1969). Linkage and Dominance Studies of Genes Controlling Methionine Synthesis in Salmonella typhimurium. Ph.D. Thesis, Birmingham University.

Chater, K. F. \& Rowbury, R. J. (1970). A genetical study of the feedback sensitive enzyme of methionine synthesis in Salmonella typhimurium. Journal of General Microbiology 63, I I I-I 20.

Childs, J. D. \& SMITH, D. A. (1969). New methionine structural gene in Salmonella typhimurium. Journal of Bacteriology Ioo, 377-382.

Cox, R. \& SMITH, R. C. (I969). Inhibition of $S$-adenosylmethionine formation by analogues of methionine. Archives of Biochemistry and Biophysics 129, 6I 5-6I9.

FINK, G. R. \& RотH, J. R. (1968). Histidine regulatory mutants in Salmonella typhimurium. VI. Dominance studies. Journal of Molecular Biology 33, 547-557.

Greene, R. C., Su, C.-H. \& Holloway, C. T. (1970). $S$-Adenosylmethionine synthetase deficient mutants of Escherichia coli $\mathrm{K}_{12}$ with impaired control of methionine biosynthesis. Biochemical and Biophysical Research Communications 38, I $120-$ I 126.

Gross, T. S. (1969). Biochemical Aspects of the Regulation of Methionine Biosynthesis in Salmonella typhimurium. Ph.D. Thesis, University College, London University. 
Gross, T. S. \& RowbURy, R. J. (1969). Methionyl transfer RNA synthetase mutants of Salmonella typhimurium which have normal control of the methionine biosynthetic enzymes. Biochimica et Biophysica Acta 184, 233-236.

Hirota, Y. (I960). The effect of acridine dyes on mating type factors in Escherichia coli. Proceedings of the National Academy of Sciences of the United States of America 46, 57-64.

Iто, J. (1969). Hybrid anthranilate synthetase molecules from Enterobacterial sources. Nature, London 223, 57-59.

Kaplan, M. M. \& Flavin, M. (1966). Cystathionine- $\gamma$-synthetase of Salmonella. Structural properties of a new enzyme in bacterial methionine biosynthesis. Journal of Biological Chemistry 24I, $578 \mathrm{I}-5789$.

Lawrence, D. A., Smith, D. A. \& Rowbury, R. J. (I968). Regulation of methionine synthesis in Salmonella typhimurium: mutants resistant to inhibition by analogues of methionine. Genetics, Princeton 58, 473-492.

LeE, L.-W., RAVEL, J. M. \& ShIVE, W. (I966). Multimetabolite control of a biosynthetic pathway by sequential metabolites. Journal of Biological Chemistry 24I, 5479-5480.

Muller-Hill, B., Crapo, L. \& Gilbert, W. (I968). Mutants that make more lac repressor. Proceedings of the National Academy of Sciences of the United States of America 59, 1259-1264.

OKadA, M., Watanabe, T. \& MiYake, T. (I968). On the nature of the recipient ability of Salmonella typhimurium for foreign deoxyribonucleic acids. Journal of General Microbiology 50, 24I-252.

Piperno, J. R. \& OXender, D. L. (1968). Amino acid transport systems in Escherichia coli $\mathrm{K}$ I2. Journal of Biological Chemistry 243, 5914-5920.

RowBURY, R. J. (1968). The inhibitory action of $\alpha$-methylmethionine on Escherichia coli. Journal of General Microbiology 52, 223-230.

Rowbury, R. J. \& Woods, D. D. (1964). Repression by methionine of cystathionase formation in Escherichia coli. Journal of General Microbiology 35, $145-\mathrm{r} 58$.

SANDERSON, K. E. (1967). Revised linkage map of Salmonella typhimurium. Bacteriological Reviews 3I, 354-372.

Sanderson, K. E. \& Demerec, M. (1965). The linkage map of Salmonella typhimurium. Genetics, Princeton 5I, 897-913.

SCHLESINGER, S. (1967). Inhibition of growth of Escherichia coli and of homoserine-O-transsuccinylase by $\alpha$-methylmethionine. Journal of Bacteriology 94, 327-332.

Sмттн, D. A. (1961). Some aspects of the genetics of methionineless mutants of Salmonella typhimurium. Journal of General Microbiology 24, 335-353.

Sмiтh, D. A. \& ChiLds, J. D. (1966). Methionine genes and enzymes of Salmonella typhimurium. Heredity 21, 265-286.

SMIth, H. O. \& LeVINE, M. (1967). A phage P 22 gene controlling integration of prophage. Virology 31, 207-216.

SPIZEK, J. \& JANECEK, J. (I969). The effect of ethionine on the synthesis of $\beta$-galactosidase: formation of an immunologically cross-reacting protein. Biochemical and Biophysical Research Communications 34, 17-21. 